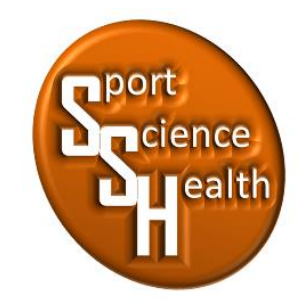

ISSN 2715-3886

\title{
Survei Keterampilan Gerak Dasar Lokomotor, Nonlokomotor dan Manipulatif pada Siswa Kelas VII Sekolah Menengah Pertama
}

\author{
Dony Navia Pratama ${ }^{1 *}$, Siti Nurrochmah ${ }^{2}$ \\ 1,2Jurusan Pendidikan Jasmani, Kesehatan dan Rekreasi, Fakultas IImu Keolahragaan, \\ Universitas Negeri Malang, Jalan Semarang No 5, Malang, Jawa Timur, 65145, Indonesia \\ *Penulis koresponden: doninavia11@gmail.com, 085708683184
}

Artikel diterima: 18 Agustus 2020; direvisi: 14 September 2020; disetujui: 18 September 2020

\begin{abstract}
Basic movement skills in physical education have been taught at the elementary school level. But the reality of the results of observations while participating in PJOK learning, most of the students in grade VII SMP N 8 Malang have difficulty practicing sport techniques. The results of interviews with teachers said that the condition was because students came from different primary school education backgrounds. Physical education teacher also said that he has never been held a basic motion skills test for grade VII students. The purpose of this study was to obtain and examine information the condition of locomotor, nonlocomotor and manipulative basic motion skills in grade VII students of SMP Negeri 8 Kota Malang. This research uses a quantitative descriptive design with a survey method. It can be concluded basic motion skills in grade VII students of SMP Negeri 8 Kota Malang (1) locomotor base motion in quite good condition, (2) nonlocomotor base motion in poor condition, (3) manipulative base motion in quite good condition. So it can be concluded that the basic locomotor, non-locomotor and manipulative movement skills of the VII grade students of SMP 8 Malang City are at a low and good enough level.
\end{abstract}

Keyword: basic motion, locomotor, nonlocomotor, manipulative.

Abstrak: Keterampilan gerak dasar dalam pendidikan jasmani telah diajarkan di jenjang pendidikan Sekolah Dasar (SD). Namun kenyataannya, hasil observasi saat mengikuti pembelajaran PJOK, sebagian besar siswa kelas VII SMP N 8 Malang mengalami kesulitan melakukan praktik teknik olahraga. Hasil wawancara dengan guru mengatakan bahwa kondisi itu karena siswa berasal dari latar belakang pendidikan sekolah dasar yang berbeda. Guru PJOK juga mengatakan belum pernah mengadakan tes keterampilan gerak dasar untuk siswa kelas VII. Tujuan penelitian ini untuk memperoleh dan mengkaji informasi kondisi keterampilan gerak dasar lokomotor, nonlokomotor dan manipulatif pada siswa kelas VII di SMP Negeri 8 Kota Malang. Penelitian ini menggunakan rancangan deskriptif kuantitatif dengan metode survei. Berdasarkan analisis data keterampilan gerak dasar siswa kelas VII di SMP Negeri 8 Kota Malang (1) gerak dasar lokomotor tergolong pada kondisi cukup baik, (2) gerak dasar nonlokomotor tergolong pada kondisi kurang baik, (3) gerak dasar manipulatif tergolong dalam kondisi cukup baik. Sehingga dapat disimpulkan bahwa keterampilan gerak dasar lokomotor, nonlokomotor dan manipulatif siswa kelas VII SMP 8 Kota Malang pada taraf kurang dan cukup baik.

Kata kunci: gerak dasar, lokomotor, nonlokomotor, manipulatif 


\section{PENDAHULUAN}

Gerak dasar merupakan suatu keterampilan dasar yang memiliki tujuan untuk mengembangkan berbagai keterampilan teknik dasar olahraga yang melibatkan anggota gerak tubuh (Wiarto, 2015). Pendapat tersebut memiliki arti bahwa gerak dasar merupakan dasar untuk mempelajari serta mengembangkan keterampilan teknik olahraga yang lebih kompleks, sehingga gerak dasar secara tidak langsung melikiki peran dalam meningkatkan kebugan jasmani dan prestasi olahraga. Pernyataan tersebut diperkuat dengan hasil penelitian yang menunjukkan bahwa keterampilan gerak dasar mempunyai kontribusi yang signifikan dengan keterampilan bermain sepak bola (Nusufi, 2016). Selain itu, hasil penelitian lain yang menunjukkan bahwa ada perbedaan antara siswa yang memiliki keterampilan gerak dasar pada kategori tinggi dan keterampilan gerak dasar pada kategori rendah terhadap peningkatan sprint 100 meter pada siswa Putra Ekstrakulikuler Olahraga Kelas VI SD Wonokerso III Kedawung (Muharram, 2015). Penelitian lain yang menunjukkan bahwa gerak fundamental berkontribusi secara signifikan dengan keterampilan bermain Small Sided Handball Games (Fadilah, 2018). Pernyataan tersebut sejalan dengan hasil penelitian yang menunjukkan bahwa keterampilan motorik memberikan kontribusi terhadap kesegaran jasmani siswa sekolah dasar (Sepriadi, 2017).

Karena pentingnya keterampilan gerak dasar seperti yang sudah dibahas sebelumnya, keterampilan gerak dasar hendaknya diajarkan secara intensif kepada siswa mulai dari jenjang sekolah dasar. Namun kenyataannya yang terjadi pada saat ini justru keterampilan gerak dasar yang dimiliki siswa jenjang SMP tidak sesuai dengan yang diharapkan. Kondisi tersebut dibuktikan oleh penelitian mengenai keterampilan motorik siswa-siswi sekolah menengah pertama full day school dan reguler di kota malang dengan hasil yang menunjukan bahwa keterampilan motorik siswa SMP full day school tergolong dalam kategori kurang dengan jumlah 70 siswa $(36,08 \%)$, sedangkan untuk siswa SMP reguler tergolong dalam kategori sedang dengan jumlah siswa 19 siswa $(35,85 \%)$ (Rahman, 2018). Penelitian serupa tentang keterampilan gerak siswa putra kelas VIII tingkat SLTP di kecamatan Pucanglaban dengan hasil yang menunjukan bahwa siswa putra kelas VIII tingkat SLTP di kecamatan Pucanglaban memiliki keterampilan gerak (motor ability) berkategori kurang sebesar $92,2 \%$. Dari kedua penelitian diatas dapat diketahui bahwa keterampilan gerak dasar siswa SMP masih tergolong kategori kurang (Buchur, 2018).

Kondisi tersebut mencerminkan adanya kesenjangan antara rendahnya keterampilan gerak dasar yang dimiliki siswa, padahal di sisi lain sudah jelas bahwasannya keterampilan gerak dasar tersebut memiliki peran yang sangat penting dan tidak tergantikan terhadap kualitas seseorang dalam melakukan suatu keterampilan olahraga. Berdasarkan kesenjangan tersebut, maka guru PJOK harus membuat rancangan pembelajaran yang sesuai untuk siswa agar keterampilannya meningkat. Untuk membuat rancangan pembelajaran guru PJOK mengetahui kondisi awal gerak dari siswa, sehingga perlu diadakan tes pengukuran tentang keterampilan gerak dasar lokomotor, nonlokomotor dan manipulatif. Dengan demikian penting diadakan penelitian tentang pengukuran keterampilan gerak dasar lokomotor, nonlokomotor dan manipulatif agar guru PJOK bisa membuat rancangan pembelajaran sehingga keterampilan gerak siswa yang masih rendah bisa diperbaiki menjadi lebih baik.

Hasil penelitian terdahulu dengan judul penelitian "Analisis Gerak Dasar Anak Usia 6-7 Tahun" yang menunjukkan hasil secara keseluruhan gerak dasar siswa SMP dalam kategori cukup, yang mana pada gerak dasar lokomotor dengan presentase $77,4 \%$ kategori cukup, gerak dasar nonlokomotor dengan presentase $74,5 \%$ kategori cukup, dan gerak dasar manipulatif dengan presentase $79 \%$ kategori baik (Kurniawan, 2018). Penelitian lain dengan judul "Analisis Gerak Motorik Dasar Siswa Kelas VII SMP Negeri 1 Kecamatan Kuok Kabupaten Kampar" yang menunjukkan hasil secara keseluruhan gerak dasar siswa SMP dalam kategori cukup, yang mana pada gerak dasar lokomotor dengan presentase 49,1\% kategori cukup, gerak dasar nonlokomotor dengan presentase $65,6 \%$ kategori baik, dan gerak dasar manipulatif dengan presentase $49,5 \%$ kategori cukup (Rezki, 2016). Untuk mendukung ketersediaan informasi, peneliti telah melakukan observasi dengan melakukan wawancara kepada guru olahraga di SMP Negeri 8 Malang. Hasil observasi menunjukkan bahwa cukup banyak siswa kelas VII yang mengalami kesulitan dalam melakukan praktik olahraga pada saat mengikuti pembelajaran pendidikan jasmani. Di SMP Negeri 8 Malang sendiri belum pernah mengetahui secara pasti berapa besar tingkat keterampilan gerak dasar lokomotor, non lokomotor dan manipulatif.

Berdasarkan ulasan teori dan penelitian terdahulu, serta hasil observasi yang telah dilakukan, peneliti melakukan penelitian dengan judul "Survei Keterampilan Gerak Dasar Lokomotor, Non-lokomotor, dan Manipulatif Pada Siswa Kelas VII di SMP Negeri 8 Kota Malang". Maka tujuan dalam penelitian ini untuk 
memperoleh dan mengkaji informasi kondisi keterampilan gerak dasar lokomotor, nonlokomotor dan manipulatif pada siswa kelas VII di SMP Negeri 8 Kota Malang.

\section{METODE}

Penelitian ini menggunakan rancangan penelitian deskriptif dengan jenis penelitian kuantitatif, untuk metode yang digunakan dalam penelitian ini adalah metode survei. Populasi siswa SMP N 8 kelas VII berjumlah 255 siswa, pengambilan sampel menggunakan teknik proporsional purposive random sampling dengan porsi $50 \%$, pengambilan sampel dilakukan dengan cara mengambil siswa dari setiap kelas dengan rata-rata jumlah 16 siswa dan diambil secara acak, sehingga jumlah sampel dari ke delapan kelas tersebut berjumlah 128 siswa dengan 60 siswa putra dan 68 siswa putri. Instrumen yang digunakan dalam penelitian ini adalah instumen tes yaitu tes keterampilan gerak dasar lokomotor berupa tes lari zig-zag lurus, side hop, loncat melewati balok; keterampilan gerak dasar nonlokomotor berupa tes kruss wiber dan kayang; dan keterampilan gerak dasar manipulatif meliputi lempar bola tangan ke sasaran dan drible zig-zag bolabasket. Teknik analisis yang digunakan dalam penelitian ini adalah teknik statistika deskriptif kuantitatif bentuk tendensi central meliputi mean, modus, min, maks, median dan teknik statistika variabilita / penyebaran data berupa standart deviasi, varians, koefisien varians dan presentase.

\section{HASIL}

Data yang telah diperoleh kemudian dianalisis menggunakan teknik statistika deskriptif teknik penyebaran data (variabel data). Berikut ini disajikan hasil analisis data keseluruhan keterampilan gerak dasar lokomotor, nonlokomotor dan manipulatif.

Tabel 1 Hasil Analisis Keseluruhan Butir Tes Siswa Putra Kelas VII SMP 8 Kota Malang

\begin{tabular}{llccc}
\hline \multirow{2}{*}{$\begin{array}{c}\text { Macam Gerak } \\
\text { Dasar }\end{array}$} & \multicolumn{1}{c}{ Jenis Tes } & \multicolumn{3}{c}{ Statistika Variabilita } \\
\cline { 2 - 5 } Lokomotor & Lari zig-zag lurus & Mean & SD & KV(\%) \\
& Side hop & 19,31 detik & 0,74 detik & 8,92 \\
& Loncat melewati balok & $12,13 \mathrm{kali}$ & $6,30 \mathrm{kali}$ & 32,15 \\
\multirow{4}{*}{ Nonlokomotor } & $6,85 \mathrm{kali}$ & 15,21 \\
& Kruss wiber & $74,94 \mathrm{~cm}$ & $10,69 \mathrm{~cm}$ & 14,26 \\
Manipulaif & Kayang & 17,38 poin & 5,83 poin & 33,53 \\
& Lempar bolatangan ke sasaran & 7,64 detik & 1,19 detik & 15,52 \\
& Dribble zig-zag bolabasket & & & \\
\hline
\end{tabular}

$\begin{array}{ll}\text { Keterangan: } \\ \text { Mean } & \text { : Rata-rata hitung } \\ \text { SD } & \text { : Standard deviasi } \\ \text { KV } & \text { : Koefisien variansi }\end{array}$

Berdasarkan hasil analis data yang diperoleh dari tes keterampilan gerak dasar lokomotor siswa putra kelas VII SMP Negeri 8 Kota Malang menyatakan bahwa unsure lari dengan tes lari zig-zag lurus di peroleh hasil dengan skor mean sampel 8,31 detik, skor standart deviasi sampel 0,74 detik, dan skor koefisien variansi $8,92 \%$. Sedangkan unsur lompat dengan tes side hop diperoleh hasil dengan skor mean sampel 19,58 kali, skor standart deviasi sampel 6,30 kali, dan skor koefisien variansi 32,15\%. Sedangkan unsur loncat dengan tes loncat melewati balok di peroleh hasil dengan skor mean sampel 12,13 kali, skor standart deviasi sampel 1,85 kali, dan skor koefisien variansi $15,21 \%$. Keterampilan gerak dasar nonlokomotor siswa putra kelas VII SMP Negeri 8 Kota Malang menyatakan bahwa tes kruss wiber di peroleh hasil dengan skor mean sampel 6,42 poin, skor standart deviasi sampel 4,62 poin, dan skor koefisien variansi $71,98 \%$. Sedangkan tes kayang diperoleh hasil dengan skor mean sampel 74,94 cm, skor standart deviasi sampel 10,69 cm, dan skor koefisien variansi $14,26 \%$. Keterampilan gerak dasar manipulatif siswa putra kelas VII SMP Negeri 8 Kota Malang menyatakan bahwa tes lempar bolatangan ke sasaran di peroleh hasil dengan skor mean sampel 17,38 poin, skor standart deviasi sampel 5,83 poin, dan skor koefisien variansi 33,53\%. Sedangkan tes dribble zig-zag 
bolabasket diperoleh hasil dengan skor mean sampel 7,64 detik, skor standart deviasi sampel 1,19 detik, dan skor koefisien variansi $15,52 \%$.

Tabel 2 Hasil Analisis Keseluruhan Butir Tes Siswa Putra Kelas VII SMP 8 Kota Malang

\begin{tabular}{|c|c|c|c|c|}
\hline \multirow{2}{*}{$\begin{array}{c}\text { Macam Gerak } \\
\text { Dasar }\end{array}$} & \multirow{2}{*}{ Jenis Tes } & \multicolumn{3}{|c|}{ Statistika Variabilita } \\
\hline & & Mean S & SD & KV(\%) \\
\hline \multirow[t]{3}{*}{ Lokomotor } & Lari zig-zag lurus & 8,97 detik & 0,92 detik & 10,25 \\
\hline & Side hop & 14,44 kali & 4,69 kali & 32,44 \\
\hline & Loncat melewati balok & 11,22 kali & 1,70 kali & 15,15 \\
\hline \multirow[t]{2}{*}{ Nonlokomotor } & Kruss wiber & 6,81 poin & 4,23 poin & 62,17 \\
\hline & Kayang & $71,24 \mathrm{~cm}$ & $12,48 \mathrm{~cm}$ & 17,52 \\
\hline \multirow[t]{2}{*}{ Manipulaif } & Lempar bolatangan ke sasaran & 16,84 poin & 6,71 poin & 39,84 \\
\hline & Dribble zig-zag bolabasket & 9,29 detik & 2,37 detik & 25,54 \\
\hline
\end{tabular}

$\begin{array}{ll}\text { Keterangan: } \\ \text { Mean } & \text { : Rata-rata hitung } \\ \text { SD } & \text { : Standard deviasi } \\ \text { KV } & \text { : Koefisien variansi }\end{array}$

Berdasarkan hasil analis data yang diperoleh dari tes keterampilan gerak dasar lokomotor siswa putri kelas VII SMP Negeri 8 Kota Malang menyatakan unsure lari dengan tes lari zig-zag lurus di peroleh hasil dengan skor mean sampel 8,97 detik, skor standart deviasi sampel 0,92 detik, dan skor koefisien variansi 10,25\%. Sedangkan unsur lompat dengan tes side hop diperoleh hasil dengan skor mean sampel 14,44 kali, skor standart deviasi sampel 4,69 kali, dan skor koefisien variansi 32,44\%. Sedangkan unsur loncat dengan tes loncat melewati balok di peroleh hasil dengan skor mean sampel 11,22 kali, skor standart deviasi sampel 1,70 kali, dan skor koefisien variansi $15,15 \%$. Keterampilan gerak dasar nonlokomotor siswa putri kelas VII SMP Negeri 8 Kota Malang menyatakan bahwa tes kruss wiber di peroleh hasil dengan skor mean sampel 6,81 poin, skor standart deviasi sampel 4,23 poin, dan skor koefisien variansi $62,17 \%$. Sedangkan tes kayang diperoleh hasil dengan skor mean sampel $71,24 \mathrm{~cm}$, skor standart deviasi sampel 12,48 cm, dan skor koefisien variansi $17,52 \%$. Keterampilan gerak dasar manipulatif siswa putra kelas VII SMP Negeri 8 Kota Malang menyatakan bahwa tes lempar bolatangan ke sasaran di peroleh hasil dengan skor mean sampel 16,84 poin, skor standart deviasi sampel 6,71 poin, dan skor koefisien variansi $39,84 \%$. Sedangkan tes dribble zig-zag bolabasket diperoleh hasil dengan skor mean sampel 9,29 detik, skor standart deviasi sampel 2,37 detik, dan skor koefisien variansi $25,54 \%$.

Setelah melalui analisi data maka data dikelompokkan dalam tabel norma yang dilengkapi dengan kriteria. Berikut ini hasil frekuensi terbanyak konversi tabel norma dari keseluruhan butir tes keterampilan gerak dasar lokomotor, nonlokomotor dan manipulatif.

Tabel 3 Distribusi Frekuensi Terbanyak Keseluruhan Butir Tes Siswa Putra Kelas VII SMP 8 Kota Malang

\begin{tabular}{llccc}
\hline Macam Gerak & \multicolumn{1}{c}{ Jenis Tes } & \multicolumn{3}{c}{ Frekuensi Terbanyak } \\
\cline { 3 - 5 } Dasar & \multicolumn{1}{c}{ Fo } & FR (\%) & Kriteria \\
\hline Lokomotor & Lari zig-zag lurus & 29 & 48,33 & Cukup Baik \\
& Side hop & 21 & 35 & Baik \\
& Loncat melewati balok & 23 & 38,33 & Baik \\
\multirow{3}{*}{ Nonlokomotor } & Kruss wiber & 19 & 31,67 & Tidak Baik \\
& Kayang & 24 & 40 & Cukup Baik \\
Manipulaif & Lempar bolatangan ke sasaran & 31 & 51,67 & Cukup Baik \\
& Dribble zig-zag bolabasket & 26 & 43,33 & Cukup Baik \\
\hline
\end{tabular}

Keterangan:

Fo : Frekuensi objektif

FR : Frekuensi relatif 
Berdasarkan distribusi frekuensi terbanyak seluruh butir tes siswa putra kelas VII SMP 8 Kota Malang mendapatkan hasil tes lari zig-zag lurus dominan pada kriteria cukup baik dengan persentase $48,33 \%$, tes side hop dominan pada kriteria baik dengan persentase 35\%, tes loncat melewati balok dominan pada kriteria baik dengan persentase $38,33 \%$, tes lari kruss wiber dominan pada kriteria tidak baik dengan persentase $31,67 \%$, tes kayang dominan pada kriteria cukup baik dengan persentase $40 \%$, tes lempar bolatangan ke sasaran dominan pada kriteria cukup baik dengan persentase $51,67 \%$, tes dribble zig-zag bolabasket dominan pada kriteria cukup baik dengan persentase $43,33 \%$. Tabel 3 menunjukan hasil frekuensi terbanyak siswa putra kelas VII SMP 8 Kota Malang yang melakukan tes lari zig-zag lurus, tes side hop, tes loncat melewati balok, tes kruss wiber, tes kayang, tes lempar bola tangan ke sasaran dan tes drible zig-zag bolabasket.

Tabel 4 Distribusi Frekuensi Terbanyak Keseluruhan Butir Tes Siswa Putri Kelas VII SMP 8 Kota Malang

\begin{tabular}{llccc}
\hline Macam Gerak & \multicolumn{1}{c}{ Jenis Tes } & \multicolumn{3}{c}{ Frekuensi Terbanyak } \\
\cline { 2 - 5 } Dasar & \multicolumn{1}{c}{ Fo } & FR (\%) & Kriteria \\
\hline Lokomotor & Lari zig-zag lurus & 28 & 41,18 & Cukup Baik \\
& Side hop & 25 & 36,76 & Cukup Baik \\
& Loncat melewati balok & 33 & 48,53 & Cukup Baik \\
\multirow{3}{*}{ Nonlokomotor } & 20 & 29,41 & Tidak Baik \\
& Kruss wiber & 25 & 36,76 & Cukup Baik \\
Manipulaif & Kayang & 32 & 47,06 & Cukup Baik \\
& Lempar bolatangan ke sasaran & 33 & 48,53 & Cukup Baik \\
& Dribble zig-zag bolabasket & 33 & & \\
\hline
\end{tabular}

\footnotetext{
Keterangan:

Fo : Frekuensi objektif

FR : Frekuensi relatif
}

Berdasarkan distribusu Frekuensi Relatif seluruh butir tes siswa putri kelas VII SMP 8 Kota Malang mendapatkan hasil tes lari zig-zag lurus dominan pada kriteria cukup baik dengan persentase $41,18 \%$, tes side hop dominan pada kriteria cukup baik dengan persentase $36,76 \%$, tes loncat melewati balok dominan pada kriteria cukup baik dengan persentase $48,53 \%$, tes lari kruss wiber dominan pada kriteria tidak baik dengan persentase $29,41 \%$, tes kayang dominan pada kriteria cukup baik dengan persentase $36,76 \%$, tes lempar bolatangan ke sasaran dominan pada kriteria cukup baik dengan persentase 47,06\%, tes dribble zigzag bolabasket dominan pada kriteria cukup baik dengan persentase 48,53\%. Tabel 4 menunjukan hasil frekuensi terbanyak siswa putri kelas VII SMP 8 Kota Malang yang melakukan tes lari zig-zag lurus, tes side hop, tes loncat melewati balok, tes kruss wiber, tes kayang, tes lempar bola tangan ke sasaran dan tes drible zig-zag bolabasket.

\section{PEMBAHASAN}

Hasil tes keterampilan gerak dasar lokomotor unsur lari menggunakan tes lari lari zig-zag lurus, unsur lompat menggunakan tes side hop, dan unsur lompat menggunakan tes loncat melewati balok pada siswa putra dan putri menunjukan dominan pada kategori cukup baik. Berarti hasil tes yang berdasarkan data dari siswa, secara keseluruhan pada unsur-unsur aspek gerak lokomotor menunjukkan hasil tes dominan kriteria cukup baik/sedang (belum baik). Kondisi keterampilan gerak dasar unsur lari, lompat dan loncat seharusnya berada dalam kondisi baik, dikarenakan pengambilan data dilaksanakan pada bulan maret, berarti kondisi siswa telah memperoleh materi pendidikan jasmani, olahraga dan kesehatan (PJOK) telah disajikan sesuai dengan kurikulum yang berlaku pada siswa kelas VII pada semester gasal dan genap, tetapi pada kenyataannya keterampilan gerak dasar unsur lari, lompat, dan loncat berada dalam belum baik. Hal yang menyebakan berada pada kondisi tersebut adalah karena kondisi yang terjadi dalam pembelajaran PJOK di SMP 8 Kota Malang, ketika pembelajaran dalam satu lapangan digunakan tiga kelas secara bersamaan, sehingga aktivitas gerak ketika pemanasan atau pembelajaran dengan materi lari lompat, dan loncat tidak dapat dilakukan dengan maksimal. Dengan kondisi lapangan yang terbatas, maka aktifitas gerak juga terbatas sehingga berdampak pada keterampilan gerak dasar lokomotor yang meliputi unsur lari, lompat, dan loncat. 
Sehubungan dengan konsep tersebut, kenyataannya hasil tes keterampilan gerak dasar aspek lokomotor pada unsur gerak lari, lompat dan loncat dominan berada pada kriteria cukup baik/sedang sampai tidak baik. Kemampuan seseorang untuk menguasai keterampilan disebabkan oleh beberapa faktor, yaitu: (a) adanya perbedaan anthropometri antar peserta didik, (b) perbedaan usia dan jenis kelamin, (c) perbedaan kemampuan kondisi fisik secara umum, (d) perbedaan tingkat koordinasi gerak yang dimiliki oleh setiap individu, (e) pertingkat pertumbuhan dan kematangan organ fisik masing-masing peserta didik, (f) pengalaman gerak yang dilakukan sehari-hari dan (g) kondisi aspek kognitif (Adi \& Fathoni, 2019, 2020b, 2020a; Fathoni, 2018). Berarti hasil tes keterampilan gerak dasar yang berada pada katagori di bawah kriteria baik (norma dibuat berdasarkan data dari siswa kelas VII SMP N 8 Kota Malang) banyak faktor yang mempengaruhi termasuk faktor "kebiasaan" gerak yang dilakukan oleh masing-masing individu.

Jika seseorang telah memiliki kemampuan mengintegrasikan berbagai pola gerak, maka gerakan yang diperoleh akan memberikan konstribusi yang besar untuk mempelajari berbagai gerakan-gerakan lainnya (Paturusi, 2012). Berarti untuk bisa menguasai berbagai keterampilan, maka peserta didik seyogyanya memiliki kemampuan mengintegrasikan berbagai pola gerak yang dimiliki. Begitu juga dengan keterampilan gerak dasar lokomotor yang memberikan peran dalam melakukan gerakan lain dalam pembelajaran PJOK. Adapun peranan keterampilan gerak dasar lokomotor, unsur lari dapat digunakan sebagai media awal untuk aktivitas pemanasan dinamis, selain itu unsur lari juga dibutuhkan dalam pembelajaran untuk mengguasai berbagai keterampilan seperti dribble bolabasket, sepakbola, kebugaran jasmani dan pembelajaran atletik. Unsur lompat mempunyai peran penting dalam pembelajaran misalnya digunakan dalam pemanasan melibatkan unsur lompat, selain itu unsur lompat digunakan dalam pembelajaran atletik dengan materi lompat jauh. Unsur loncat umumnya digunakan dalam pemanasan dengan bentuk permainan loncat katak, selain itu unsur loncat dapat digunakan dalam pembelajaran materi kebugaran jasmani seperti gerakan loncat tegak atau loncat jauh tanpa awalan, dan materi pembelajaran senam seperti loncat harimau. Secara keseluruhan keterampilan gerak dasar lokomotor dapat berperan dalam pembelajaran PJOK. Oleh karena itu unsur-unsur dalam aspek gerak lokomotor tersebut penting untuk ditingkatkan melalui pembiasaan dalam pembelajaran atau latihan di luar jam pembelajaran.

Terkait dengan pentingnya unsur lari menguasai berbagai keterampilan, terdapat penelitian terdahulu yang menunjukkan bahwa penerapan model latihan kelincahan dapat meningkatkan keterampilan dribble dalam permainan bolabasket, sehingga penelitian tersebut menunjukkan bahwa dengan melatih unsur kelincahan lari dapat meningkatkan keterampilan dribble bolabasket (Rizaldi, 2017). Penelitian lain yang menunjukkan bahwa latihan kelincahan dapat meningkatkan keterampilan dribble sepakbola dibandingkan dengan latihan konvensional (Utama, 2015). Penelitian yang menunjukkan bahwa terdapat hubungan kecepatan dengan hasil lompat jauh pada siswa SMP, dengan kata lain latihan kecepatan lari dapat meningkatkan hasil lompat jauh (Anwar, 2020). Sedangkan dengan pentingnya unsur lompat dalam menguasai berbagai keterampilan, terdapat penelitian terdahulu yang menunjukkan bahwa latihan lompat kardus dapat berpengaruh dalam hasil lompat jauh gaya jongkok (Pratama, 2018). Penelitian lain yang menunjukan bahwa variasi latihan single leg jump dapat berpengaruh terhadap peningkatan hasil lompat jauh siswa SMP (Anto, 2019). Penelitian yang menunjukan bahwa latihan single leg speed dapat berpengaruh terhadap peningkatan hasil tendangan sepakbola siswa SMP (Wibowo, 2014). Sedangkan dengan pentingnya unsur loncat dalam menguasai berbagai keterampilan, terdapat penelitian terdahulu yang menunjukkan bahwa daya ledak otot tungkai berhubungan secara signifikan dengan kemampuan loncat harimau pada materi senam, dengan kata lain latihan daya ledak loncat dapat meningkatkan hasil loncat harimau (Sulistyanto \& Purwanto, 2013). Penelitian lain yang menunjukan bahwa latihan plyometric frog jump atau loncat katak dapat berpengaruh terhadap peningkatan hasil tendangan sepakbola siswa SMP (Wibowo, 2014). Selain itu, hasil penelitian lain menunjukkan bahwa latihan plyometric berupa jump to box berpengaruh signifikan terhadap daya ledak otot tungkai dan kemampuan smash atlet bolavoli SMAN (Oktaviani, 2020).

Hasil keterampilan gerak dasar nonlokomotor menggunakan tes kruss wiber dan tes kayang pada siswa putra dan putri menunjukan dominan pada kategori cukup baik. Berarti hasil tes yang berdasarkan data dari siswa, secara keseluruhan pada aspek gerak nonlokomotor menunjukkan hasil tes dominan kriteria kurang baik (belum baik). Komponen yang digunakan dalam melakukan kedua tes tersebut, menggunakan komponen kelentukan. Hal tersebut disebabkan oleh pembelajaran yang dilakukan guru PJOK dalam melibatkan keterampilan gerak dasar nonlokomotor (kelentukan) masih kurang karena materi kurikulum yang melibatkan gerak nonlokomotor (kelentukan) memang sedikit. Selain itu, guru PJOK juga menyampaikan bahwa siswa 
kurang aktif dalam mengikuti pembelajaran yang melibatkan aspek gerak nonlokomotor (kelentukan) dibandingkan dengan pembelajaran yang melibatkan gerak lokomotor dan manipulatif, hal itu dikarenakan siswa sering mengalami kesulitan/kesakitan dalam melakukan gerakan kelentukan.

Sehubungan dengan konsep tersebut, kenyataannya hasil tes keterampilan gerak dasar aspek nonlokomotor dominan berada pada kriteria kurang baik sampai tidak baik. Proses pembelajaran dan hasil belajar siswa disebabkan oleh beberapa faktor, yaitu: 1) faktor fisiologis terdiri dari kondisi fisik, 2) faktor psikologis terdiri dari minat, motivasi dan kecerdasan, 3) faktor lingkungan, 4) faktor instrumental terdiri dari kurikulum, guru, program dan sarana (Yudha, 2018). Berarti hasil tes keterampilan gerak dasar nonlokomotor yang berada pada kategori di bawah kriteria baik (norma dibuat berdasarkan data dari siswa kelas VII SMP N 8 Kota Malang) banyak faktor yang mempengaruhi termasuk faktor motivasi masing-masing individu dan kurikulum sebagai acuan guru untuk proses pembelajaran.

Salah satu usaha yang dilakukan guru pendidikan jasmani untuk meningkatkan kelentukan adalah melakukan pemanasan atau peregangan. Dengan demikian apabila siswa melaksanakan pembelajaran pendidikan jasmani, sebaiknya guru membiasakan untuk memerikan model pergangan dengan intesitas yang tinggi berdasarkan kebutuhan otot maupun sendi yang paling dominan, dengan adanya peregangan disetiap awal dan akhir pembelajaran secara berulang maka kelentukan akan terbentuk sendirinya. Selain itu, guru diharapkan untuk meningkatkan keaktifan siswa agar aktivitas gerak kelentukan meningkat. Salah satu cara meningkatkan keaktifan siswa melalui pembelajaran menggunakan metode bermain, pembelajaran yang di desain dengan permaian akan membuat anak menjadi aktif sehingga pembelajaran akan tersampaikan secara maksimal. Selain dengan meningkatkan kelentukan siswa menggunakan peregangan dan keaktifan, guru bisa menggunakan pelatihan yoga.

Terkait dengan cara meningkatkan kelentukan. Terdapat penelitian terdahulu yang menunjukkan bahwa peregangan yang dilakukan secara berulang pada setiap kali latihan dengan intensitas tinggi dan intensitas sedang mampu meningkatkan kelentukan dibandingkan dengan peregangan intensitas rendah (Lim, 2018). Selain itu, hasil penelitian lain yang menunjukkan bahwa latihan peregangan statis lebih efektif terhadap peningkatan kelentukan togok dibandingakan dengan latihan peregangan dinamis. Sedangkan cara meningkatakan keaktifan siswa (Suharjana, 2013). Terdapat penelitian terdahulu dengan hasil penelitian yang menunjukkan bahwa keaktifan siswa dalam mengikuti pembelajaran keterampilan gerak nonlokomotor dapat ditingkatkan melalui metode bermain (Akbar, 2014). Selain itu, hasil penelitian lain yang menunjukkan bahwa metode bermain dapat meningkatkan keaktifan siswa dalam mengikuti pembelajaran pendidikan jasmani dengan sub materi kebugaran jasmani (Hakim, 2018). Penelitian lain dangan hasil penelitian yang menunjukkan bahwa pelatihan yoga dapat meningkatkan kelentukan seseorang (Mertayasa, 2013).

Keterampilan gerak dasar manipulatif pada siswa kelas VII di SMP Negeri 8 Kota Malang menggunakan dua butir tes yaitu tes lempar bolatangan ke sasaran dan tes dribble zig-zag bolabasket. Berdasarkan hasil analisis tes lempar bolatangan ke sasaran, untuk siswa putra hasil tes menunjukkan dominan pada kategori cukup baik dan siswa putri hasil tes menunjukkan dominan pada kategori cukup baik. Sedangkan hasil analisis tes dribble zig-zag bolabasket, untuk siswa putra hasil tes menunjukkan dominan pada kategori cukup baik dan siswa putri hasil tes menunjukkan dominan pada kategori cukup baik. Berarti hasil tes yang berdasarkan data dari siswa putra dan putri, secara keseluruhan pada aspek manipulatif menunjukan dominan pada kategori cukup baik (belum baik). Hasil tes gerak manipulatif yang dominan kriteria cukup baik (belum baik) di karenakan aktivitas gerak menggunakan alat yang dilakukan siswa masih kurang. Hal tersebut disebabkan kondisi dalam proses pembelajaran PJOK di SMP Negeri 8 kota dilaksanakan tiga kelas secara bersamaan, sehingga peralatan dan lapangan yang digunakan untuk pembelajaran terbagi dengan kelas lain, yang mengakibatkan siswa kurang maksimal dalam melakukan gerak manipulatif. Keterampilan gerak dasar aspek manipulatif sangat banyak dibutuhkan dalam melakukan gerakan pada cabang olahraga yang menggunakan alat.

Sehubungan dengan konsep tersebut, kenyataannya hasil tes keterampilan gerak dasar aspek maniulatif pada siswa putra dan puri dominan berada di kriteria cukup baik/sedang sampai tidak baik. Perkembangan keterampilan gerak disebabkan oleh beberapa faktor, yaitu: 1) kesempatan berlatih, latihan yang dilakukan secara berulang akan membentuk keterampilan gerak yang didukung aspek lapangan yang luas; fasilitas yang memadai; dan waktu yang lama, 2) dorongan semangat, semangat yang dimikiki akan berpengaruh dengan rajinnya latihan sehingga dapat mengembangkan keterampilan gerak, 3) pengajaran yang dilakukan oleh 
guru, berfungsi untuk memberikan pertolongan kepada anak yang kesulitan melakukan keterampilan gerak, sehingga anak dapat melakukan keterampilan gerak secara luas (Sudirjo \& Nur, 2019). Berarti hasil tes keterampilan gerak dasar manipulatif yang berada pada kategori di bawah kriteria baik (norma dibuat berdasarkan data dari siswa kelas VII SMP N 8 Kota Malang) banyak faktor yang mempengaruhi termasuk faktor kesempatan berlatih dan pengajaran.

Adapun hal yang dilakukan guru untuk meningkatkan keterampilan gerak manipulatif, yaitu pembelajaran menggunakan metode drill, metode drill merupakan metode yang digunakan untuk mengulang gerakan secara terus menerus, sehingga secara tidak langsung siswa mendapat pengalaman gerak secara berulang. Selain itu, guru juga dapat menggunakan metode part and whole atau bagian dan keseluruhan, metode ini diajarkan mulai dari bagian-bagian tertentu kemudian dirangkai menjadi satu gerakan keseluruhan, sehingga selain mendapat gerakan secara keseluruhan anak juga mendapatkan gerakan secara detai untuk keterampilan gerak tertentu. Selain metode yang digunakan dalam pembelajaran guru PJOK bisa memodifikasi alat untuk meningkatkan katerampilan gerak manipuatif.

Terkait dengan cara meningkatkan keterampilan gerak manipulatif, terdapat penelitian terdahulu yang dilakukan oleh menyatakan bahwa pembelajaran menggunakan metode drill dinamis dan statis dapat meningkatkan hasil belajar lempar jauh bola softball (Pradana, 2019). Selain itu, hasil penelitian lain yang menunjukkan bahwa terdapat peningkatan hasil belajar dribble bolabasket sebelum dan sesudah pembelajaran menggunakan metode drill (Oktaviani, 2017). Penelitian lain dengan hasil penelitian menunjukan bahwa metode part and whole dapat meningkatakan keterampilan dribble bolabasket (Baqiyudin, 2013). Selain itu hasil penelitian yang menunjukkan bahwa modifikasi alat lembing dapat meningkatkan gerak dasar lempar lembing anak siswa kelas 5 SD (Wijayanti \& Suntoda, 2017). Selain itu, hasil penelitian lain menunjukkan bahwa modifikasi bola basket menggunakan bola voli dapat berpengaruh terhadap hasil belajar dribble bolabasket siswa SMP kelas VII (Pralista, 2017). Dari beberapa hasil penelitian tersebut bisa disimpulkan bahwa keterampilan menggiring dan melempar (keterampilan gerak dasar manipulatif) dapat ditingkatkan melalui metode drill dan metode part and whole serta modifikasi alat.

\section{KESIMPULAN}

Berdasarkan hasil penelitian mengenai kondisi keterampilan gerak dasar lokomotor, nonlokomotor dan manipulatif pada siswa kelas VII di SMP 8 Kota Malang, maka kesimpulan hasil penelitian dapat dirumuskan, sebagai berikut: (1) Kondisi keterampilan gerak dasar lokomotor dari ketiga unsur yaitu lari, lompat dan loncat untuk siswa SMP 8 Kota Malang tergolong pada kriteria sedang/cukup baik (belum baik), (2) Kondisi keterampilan gerak dasar nonlokomotor dari kedua butir tes yaitu tes kruss wiber dan tes kayang untuk siswa SMP 8 Kota Malang tergolong pada kriteria kurang baik (belum baik), (3) Kondisi keterampilan gerak dasar manipulatif dari kedua butir tes yaitu tes lempar bolatangan ke sasaan dan tes dribble zig-zag bolabasket siswa SMP 8 Kota Malang tergolong pada kriteria sedang/cukup baik (belum baik).

Berdasarkan hasil analisis data dalam penelitian ini, peneliti mengajukan saran sebagai berikut: (1) Guru PJOK, (a) penting mengadakan tes awal tentang keterampilan gerak dasar lokomotor, nonlokomotor dan manipulatif diawal semester gasal untuk digunakan sebagai dasar dalam menyusun Rencana Pelaksanaan Pembelajaran. (b) meningkatkan proses pembelajaran lebih banyak siswa aktif bergerak mengingat kelas VII merupakan masa transisi, dimana keterampilan gerak dasar dalam membentuk gerak yang lebih kompleks, (2) Bagi Siswa SMP N 8 Kota Malang, peneliti sarankan untuk lebih sering melakukan akivitas gerak keterampilan dasar secara mandiri ketika pembelajaran PJOK atau diluar jam pelajaran kokurikuler, agar kondisi keterampilan gerak dasar dapat meningkat pada kriteria baik, (3) Bagi calon peneliti lainnya, (a) dapat mengadakan tes keterampilan gerak dasar menggunakan butir-butir yang telah divalidasikan untuk Sekolah Menengah Pertama (SMP) di luar kota Malang atau di kota Malang tapi di sekolah yang bukan Sekolah Negeri. (b) melakukan penelitian tentang tes keterampilan gerak dasar menggunakan butir tes yang lainnya.

\section{DAFTAR PUSTAKA}

Adi, S., \& Fathoni, A. F. (2019). Development of Learning Model Based on Blended Learning in Sports School. https://doi.org/10.2991/acpes-19.2019.2 
Adi, S., \& Fathoni, A. F. (2020a). Blended Learning Analysis for Sports Schools in Indonesia. International Journal of Interactive Mobile Technologies (IJIM), 14(12), 149-164. Retrieved from https://www.onlinejournals.org/index.php/i-jim/index

Adi, S., \& Fathoni, A. F. (2020b). The effectiveness and efficiency of blended learning at sport schools in Indonesia. International Journal of Innovation, Creativity and Change.

Akbar, F. 2014. Meningkatkan Keaktifan Siswa Dalam Pembelajaran Gerak Lokomotor, Nonlokomotor dan Manipulatif Dengan Metode Bermain Pada Siswa Kelas III SD Negeri 01 Tlogowaru Kota Malang. Skripsi tidak diterbitkan. Malang: Universitas Negeri Malang

Anto, A.H. 2019. Pengaruh Variasi Latihan Single Leg Jump Terhadap Peningkatan Hasil Lompat Jauh Siswa Smp Islam Al-Falah Kota Jambi. Indonesian Journal of Sport Science and Coaching, 3(1), 75-80 http://www.online-journal.unja.ac.id/IJSSC/article/view/7514/4657

Anwar, Y. 2020. Kontribusi Kecepatan dan Daya Ledak terhadap Hasil Lompat Jauh Pada Siswa SMP Negeri 2 Lengayang. Sport Science, 20(1), 18-31 http://doi.org/10.24036/jss.v20i1.35

Baqiyudin, G. 2013. Perbandingan Metode Pembelajaran Whole Practice dan Part Practice Terhadap Hasil Belajar Dribbling Bolabasket (Studi Pada Siswa Kelas Vii Smpn 1 Jogoroto Jombang). Jurnal $\begin{array}{lllll}\text { Pendidikan Olahraga dan } \quad \text { Kesehatan, } & \text { 1(1), }\end{array}$ http://jurnalmahasiswa.unesa.ac.id/index.php/jurnal-pendidikan-jasmani/article/view/2837

Buchur, A. 2018. Survei Tingkat Keterampilan Gerak (Motor Ability) Siswa Putra Kelas Viii Tingkat Sltp SeKecamatan Pucanglaban Kabupaten Tulungagung Tahun Ajaran 2017/2018. Jurnal Simki-Techsain, 2(5), 1-12 http://simki.unpkediri.ac.id/detail/13.1.01.09.0116

Fadilah, M. 2018. Kontribusi Keterampilan Gerak Fundamental Terhadap Keterampilan Bermain SmallSided Handball Games. Jurnal Pendidikan Jasmani dan Olahraga. 3(1), 60-68 DOI: 10.17509/jpjo.v3i1.7667

Fathoni, A. F. (2018). The Role of Blended Learning on Cognitive Step in Education of Sport Teaching by Adjusting the Learning Style of the Students. https://doi.org/10.2991/isphe-18.2018.49

Hakim, L. 2018. Upaya Meningkatkan Keaktifan Siswa Dalam Pembelajaran Pendidikan Jasmani Menggunakan Metode Bermain Untuk Siswa Kelas V Sdn 2 Pagelaran Kabupaten Malang. Journal of Teaching Physical Education in Elementary School. 1(2), 65-77 http://doi.org/10.17509/tegar.v1i2.111940

Kurniawan, R. 2018. Analisis Gerak Dasar Anak Usia 6-7 Tahun. Jurnal Obsesi : Jurnal Pendidikan Anak Usia Dini, 12(1), 12-19 https://doi.org/10.2991 /icece-16.2017.3

Lim, W. 2018. Easy Method for Measuring Stretching Intensities in Real Clinical Setting and Effects of Different Stretching Intensities on Flexibility. Jurnal of Back and Musculoskeletal Rehabilitation, 1, 1-7 https://doi.org/10.3233/BMR-181243

Mertayasa, K. 2013. Pengaruh Pelatihan Yoga Asana (Suryanamaskar) terhadap Kelentukan dan Kapasitas Vital Paru. Jurnal Ilmu Keolahragaan Undiksha, 1(1), 1-8 http://dx.doi.org/10.23887/jiku.v1i1.1578.

Muharram, A. 2015. Pengaruh Pembelajaran Dan Keterampilan Gerak Dasar Terhadap Peningkatan Keterampilan Sprint 100 Meter. Jurnal Sportif, 1(1) 22-31 https://doi.org/10.29407/js_unpgri.v1i1.572

Nusufi, M. 2016. Hubungan Keterampilan Motor Ability Dengan Keterampilan Bermain Sepak Bola Pada Klub Himadirga Unsyiah. Jurnal Pedagogik Keolahragaan, 2(1), 1-10 https:/jurnal.unimed.ac.id/2012/ index.php /jpor/article/view/4504

Oktaviani, S. 2017. Pengeruh Pembelajaran Metode Drill dan Komando Terhadap Peningkatan Hasil Belajar Dribble Bolabaket Siswa Kelas XI. Prosiding Seminar Nasional Implementasi Olahraga, Kesehatan Dan Pendidikan Jasmani Terhadap Upaya Peningkatan Karakter Anak Bangsa, 137-144 https://www.researchgate.net/profile/Adi_Sumarsono/publication/333882436_3_JULI_2018_PROSIDI NG_SEMNAS_OR_UM_MALANG/links/5d0ad130a6fdcc35c15bb5f5/3-JULI-2018-PROSIDINGSEMNAS-OR-UM-MALANG.pdf\#page $=146$ 
Oktaviani, S. M. 2020. Pengaruh Latihan Plyometrics Terhadap Kemampuan Daya Ledak Otot Tungkai dan Kemampuan Smash Atlet Bolavoli SMAN 01 Mukomuko. Jurnal Patriot, 3(1), 526-536. https://doi.org/10.24036/patriot.v2i1.595

Paturusi. 2012. Manajemen Pendidikan Jasmani dan Olahraga. Jakarta: Rineka Cipta

Pradana, A. 2019. Pengaruh Pembelajaran Metode Drill Terhadap Peningkatan Hasil Belajar Lempar Bola Softball Kelas 7 Smp Negeri 1 Kota Malang. Jurnal Gelanggang Pendidikan Jasmani Indonesia,3(2), 121-129 http://dx.doi.org/10.17977/um040v3i2p121-129

Pralista, Ot. 2017. Pengaruh Modifikasi Bola Basket Terhadap Hasil Belajar Dribble (Studi pada Siswa Kelas VII-A SMP Negeri 1 Kertosono Tahun Ajaran 2015/2016). Jurnal Pendidikan Olahraga dan Kesehatan, 4(2), 345-349 https://jurnalmahasiswa.unesa.ac.id/index.php/jurnal-pendidikanjasmani/article/view/18803.

Pratama, R. 2018. Pengaruh Latihan Lompat Kardus Terhadap Hasil Lompatan Jauh Gaya Jongkok Pada Siswa SD Negeri 132 Palembang. Journal Of Sport Science And Education, 1(1), 41-46 http://dx.doi.org/10.26740/jossae.v3n1.p41-46

Rahman, G. 2018. Survei Tentang Keterampilan Motorik Siswa-Siswi Sekolah Menengah Pertama Full Day School dan Reguler. Skripsi tidak diterbitkan. Malang: Universitas Negeri Malang

Rezki, R. 2016. Analisis Gerak Motorik Dasar Siswa Kelas VII SMP Negeri 1 Kecamatan Kuok Kabupaten Kampar. Journal Sport Area, 1(1), 63-70 https://doi.org/10.30814/sportarea.v1i1.375

Rizaldi, D.A. 2017. Upaya Meningkatkan Keterampilan Dribble Dengan Penerapan Model Latihan Kelincahan. Jurnal IImiah Pendidikan Jasmani, 1(2), 125-129 http://doi.org/10.33369/jk.v1i2.3477

Sepriadi, S. 2017. Kontribusi Status Gizi dan Keterampilan Motorik terhadap Kesegaran Jasmani Siswa Sekolah Dasar. Jurnal Keolahragaan, 5(2), 194-206 http://dx.doi.org/10.21831/jk.v5i2.15147

Sudirjo, E, dan Nur, M. 2019. Filsafat Pendidikan Jasmani. Sumedang: UPI Press

Suharjana, F. 2013. Perbedaan Pengaruh Hasil Latihan Peregangan Statis Dan Dinamis Terhadap Kelentukan Togok Menurut Jenis Kelamin Anak Kelas 3 dan 4 Sekolah Dasar. Jurnal Pendidikan Jasmani Indonesia , 9(1), 38-46 http://doi.org/10.21831/jpji.v9i1.3061

Sulistyanto, dan Purwanto, H. 2013. Kontribusi Kekuatan Otot Anggota Gerak Atas Fleksibilitas Togok Dan Power Tungkai Terhadap Kemampuan Senam Loncat Harimau Siswa Putra. Jurnal Pendidikan Jasmani Indonesia , 9(1), 47-52 http://doi.org/10.21831/jpji.v9i1.3062

Utama, A.Z. 2015. Pengaruh Latihan Kelincahan Dan Kelentukan Terhadap Keterampilan Dribbling Sepakbola Ssb Pas-Itn Kabupaten Malang. Jurnal Pendidikan Jasmani, 25(1), 31-38 http://dx.doi.org/10.17977/pj.v25i1.4887

Wiarto, G. 2015. Inovasi Pembelajaran dalam Pendidikan Jasmani. Yogyakarta: Laksitis

Wibowo, A. 2016. Pengaruh Latihan Plyometric Frog Jump Dan Single Leg Speed Hop Terhadap Kemampuan Shooting Sepakbola Siswa Smpn 21 Malang. Jurnal Pendidikan Jasmani, 26(2), 398-410 http://dx.doi.org/10.17977/pj.v26i2.7519.g3434

Wijayanti, D., \& Suntoda, A. 2017. Upaya Meningkatkan Pemahaman Gerak Dasar Lempar Lembing Melalui Penerapan Lembing Modifikasi Dalam Pembelajaran Atletik. TEGAR: Journal of Teaching Physical Education in Elementary School, 1(1), 14-24 https://doi.org/10.17509/tegar.v1i1.8652

Yudha, P. 2018. Motivasi Berprestasi \& Disiplin Peserta Didik Serta Hubungannya Dengan Hasil Belajar. Pontianak: Yudha English Gallery 